\title{
The System Saving Mechanism in Russian Criminal Law
}

\author{
Anna V. Denisova* \\ Samara University \\ 1 Ak. Pavlova Str., Samara, 443011, Russia
}

Received 27.10.2015, received in revised form 29.06.2016, accepted 19.11.2016

The article deals with the features of the system saving mechanism functioning in criminal law, gives the detailed description of its structure and contents and reveals this mechanism value for providing branch integrity. Due to this mechanism, criminal law processes the branch system and makes its elements consistent and coherent. Such structural elements as the principles, purposes and objectives of criminal law, branch presumptions and fictions, prejudices, lacunes and collision rules are carefully investigated in the article. The author draws the conclusion that the studied mechanism is one of the means of self-regulation in criminal law.

Keywords: systemacity of law, criminal law, system saving mechanism, principles, purposes and objectives of criminal law, legal presumptions and fictions, prejudices, lacunes and collision rules.

DOI: 10.17516/1997-1370-2016-9-12-2928-2935.

Research area: law.

It is necessary to understand that the modern criminal law is not only a set of laws and institutions, not only a standard organization, but a legal phenomenon that includes 1) criminal law as a complex system organization formed by the standard instructions and contained in legal acts as the sources of criminal law; 2) legal institutions consisting of the criminal law and standard instructions repeated in them; 3) authorized sources of the criminal law; 4) criminal and legal relations of guarding, precautionary and regulatory character.

This list is not comprehensive, because there is a particular phenomenon in the system of criminal law that unites all aforesaid elements and provides their effective coexistence and interaction. This integrating legal phenomenon is a so-called system saving mechanism, the one that provides integrity, systemacity and the coordination interaction between all the branch elements in criminal law. It also regulates influence of external conditions on the criminal law by providing a continuity and variability combination in the process of the criminal law regulation.

Due to this mechanism a certain ordering impact on the branch components is carried out, their joint functioning is coordinated and the timely adaptation of the branch to the social changing is provided. The structure of the system

(c) Siberian Federal University. All rights reserved

* Corresponding author E-mail address: anden2012@yandex.ru 
saving mechanism includes such legal components as principles, purposes and problems of the criminal law, presumptions and fictions, lacunes and collision rules, and this mechanism operates through system communications between the above mentioned branch elements.

One of the most important elements of the system saving mechanism is the corresponding branch principles, certain ideas, which depend on a moral, political and economic condition of society and determine the lawmaking and law enforcement activity in the criminal law (Mal'tsev, 2001; Naumov, 2011). Five principles are consolidated in the existing criminal law: the principles of legality, equality of citizens before the law, fault, justice and humanity. In the doctrine of criminal law other principles of criminal law are distinguished; they are not consolidated at the legislative level. These are the principles of inevitability of responsibility and personal responsibility (Lazarev, 2009; Inogamova-Hegai, 2014).

The principles or the leading ideas give a notion about due processes in criminal law, they define what it has to be like; they are the essence of criminal law, these ideas-principles had appeared and developed long before the criminal law itself and subsequently define its content. M.M. Bablaev and Iu.E. Pudovochkin remark that the principles of criminal law carry out an important protective stabilizing function: they act as a "filter" that passes into the criminal law norms corresponding to the branch principles, and also they prevent introduction of branch elements that are incompatible with it, providing coherence and systemacity of criminal law and keeping its intrinsic properties (Babaev, 2012).

It is indisputable that the principles of criminal law are determined both as a system construction of this branch and as realization of the criminal law: principles of the criminal law provide the uniform application of the criminal law by all the subjects of law enforcement activity; they unify the law enforcement activity.

But their impact on the legislative activity is also significant. They have great influence on the improvement of the existing system of criminal law. By proclaiming the above ideasprinciples the legislator assigns on certain duties to realize them in the criminal law. Having found any discrepancy to the existing criminal law, the legislator is obliged to eliminate the revealed defect of lawmaking activity by cancelling the corresponding norm or changing its contents bringing it in compliance with the broken branch principle. Legal practice has already had similar examples. In the case of M.A. Aslamazian it was established by the constitutional court of the Russian Federation that "entering into the legal regulation of a standard situation that establishes criminal responsibility for currency smuggling, which does not allow to delimit a crime from the similar one by the objective side of an administrative offense, the federal legislator - in defiance of the Constitution Russian Federation and the international obligations of the Russian Federation - creates the possibility of any application of this situation and inadmissible substitutions of administrative responsibility into the criminal law, which contradicts the conventional principles of criminal liability, principles of the criminal legislation, and also the principles of legality, equality of citizens before the law and court, justice, humanity fixed on the basis of the Constitution of the Russian Federation and the Criminal Code of the Russian Federation (italics - A.D.), and it also does not correspond with the basis of criminal responsibility and the notion of crime..." (Skoblikov, 2009), therefore the content of the corresponding forbidding criminal law about commodity smuggling and application practice have significantly changed, and in a couple of years p.188 in the Criminal code of the Russian 
Federation it was declared as invalid, and commodity smuggling was decriminalized. Thus, the principles of criminal law provide the intra-branch unity and coherence by defining the contents and implementation of each criminal precept of law and institution, development of any criminal legal relations and content of all branch formal-legal sources, thereby these principles maintain the integrity of criminal law by being an integral part of its system saving mechanism.

The goals and objectives of a branch are also a very important element of the aforesaid mechanism, because the main characteristic of any system is integrity that is directly connected with the goals for which performance a system exists. If the goal is not specify in the explicit form (as we can observe in the Criminal Code of the Russian Federation where only tasks of the criminal legislation are listed and not the branch goals), and the studied object has complete characteristics, it is possible to define the goal or the manifestation that connects the goal with tools of its achievement (mainly it is objective functions) through studying of the emergence reasons of regularity of integrity. By dismembering the system, it is possible to analyze the emergence reasons of integrity on the basis of establishing relationships of the cause and effect connections of various natures between parts, a part and the whole, identifications of the cause and effect conditionality of the whole by its environment. It is represented that the goal of a branch of the law is a conceivable result of a certain legal and other activity, a result of functioning rules of law and others elements of the branch system.

In our opinion, the main branch goals of the criminal law are the maintenance of law enforcement inside and outside the country, and ensuring the criminal law means of safe coexistence of people in society (including admission of the social conflicts) that does not interfere in the allocation of goals of this branch of law, which have a subordinated value in relation to the aforesaid.

The goal achievement involves the consecutive solution of a number of interconnected tasks faced by the branch of the law, the problems that demand a solution; thus, the objectives act as intermediate goals of the law branch. Objectives of the criminal law are established in Part 1 Article 2 in the Criminal code of the Russian Federation (protection of the rights and freedoms of a person and a citizen, property, public order and public safety, environment, constitutional system of The Russian Federation against criminal assaults; the maintenance of peace and security of mankind, as well as the prevention of crimes). Thus, in special literature it is noted that the educational task follows directly from the last task (Pan'ko, 1998; Vlasenko, 1984)).

The next important components of the system saving mechanism of the criminal law are presumption and fiction. Traditionally, in the general theory of the law, legal presumptions are defined as means of the legal equipment, which are acceptance of the facts, communications, phenomena, situations seen as truth until the opposite is proved. It means that there are assumptions established by the law, which both the law-enforcement bodies and citizens are obliged to accept without proof until these assumptions are disproved. Thus, in the criminal law presumption is an assumption of existence or non-existence of legally significant facts, which leads to the criminal law relations' emergence (or on the contrary - stating impossibility of their emergence, for example, in a case of committing a socially dangerous act by a juvenile person provided for by the Criminal Code of the Russian Federation (fixed in Article 20 of the Criminal Code of the Russian Federation presumption of juvenile's lack of understanding the danger of the action determining all questions of juvenile 
criminal liability and corresponding procedural consequences)). Due to presumption, separate facts of the case that have legal meaning are specified and the criminal law assessment of actions is predetermined. Therefore, legal presumptions are necessary for coordination of judicial norms of both the same and different branch belonging, for stability assurance of the criminal law system, for saving of time and amount of the criminal influence means. This is the reason to accept presumptions as important components of the system saving mechanism both as a branch of the criminal law and the legal system.

In the general theory of law, it is a common understanding of legal fiction as something that does not actually exist, but is accepted as existing by the legislation. Legal fiction is a special rule that dictates to consider the nonexistent as existent, and vice versa. Thus, after expunging a criminal record a convicted person ceases to be considered as a convict, because according to provisions of Paragraph 6 Article 86 of the Criminal Code of the Russian Federation, the "expunging a criminal record or removal of conviction annuls all the legal consequences connected with the record of conviction." The special literature also reveals and investigates other kinds of criminal fiction in concept of a crime, an institution of recurrence of crimes, formal structures, conditional condemnation, institution of release from criminal liability and punishment (On the case..., 2008). We will specify that fictions are special legal means, the rules of giving the necessary visibility to legal reality, which are fixed in the text of the criminal law sources and are legitimately realized in decisions of the law-enforcement bodies. They differ from all the other criminal law environment components in the specific contents; they order to consider the nonexistent facts as existent and vice versa. It means that fictions are the specific manifestation and supplement to the criminal law; they are a reasonable attempt of legal tools to go beyond themselves, because in some cases there is a lack of giving a legal value to the nonexistent facts or deprivation of a legal value to the existent facts for the comprehensive and complete criminal regulation, thereby, there is specific processing of the system content of the criminal law, the necessary joint and harmonization of its elements are provided, it means that the necessary level of their intra-branch unity and integrity is supported. This is the reason to consider them as the important system saving mechanism components as branches of the criminal law, and as the legal system.

The next functional link in the system saving mechanism of the criminal law is prejudices. Traditionally, under a notion of prejudice we understand a procedural category, which means the question is predetermined in the sphere of judicial practice, and an important legal value of the previous judgment for the new process, a special proving rule (Tille, 1965; Lopashenko, 2004; Komissarova et al., 2013). However the notion of prejudice has material understanding in the criminal law, and, as a rule, it is connected with the existence of structures of crimes with administrative prejudice (p. 151.1, 178 of the Criminal Code of the Russian Federation, etc.). The nature of administrative prejudice is an involvement of a person into the criminal liability, if the person repeats the act during a certain period after imposing one or two administrative punishments for the same offence (Volkov, 2013; Bezverhov, 2012). The intersectoral character of such legal phenomenon means a close interaction between the criminal and the administrative law. It is represented that maintenance of enforcement and ensurance of legal means of safe coexistence of people in society are possible only as a result of close interaction of the all the branches at all levels and stages of the legal regulation, 
their constant dynamics and interpenetration to each other. All the aforesaid integrative and converting features of prejudices are caused by their inclusion in the system saving mechanism structure and through performing an important role in the process of its functioning both at the branch and the intersectoral levels.

One more element of the system saving mechanism in the criminal law is a so-called lacune rule, a doctrinal rule to reveal, overcome and eliminate gaps in the law. The special literature formulates the necessary conditions for revealing gaps in the criminal law and also offers a special algorithm of the law enforcement actions as follows:

1) it is necessary to know the existing criminal legislation to be able to be orientated, to see communication between the General and Special parts of instructions, and also their interdependence and interrelation with norms of other branches of the law;

2) at the same time it is necessary to base on the principles of criminal law, its objectives to know the practice of the criminal law application, to use legal and doctrinal interpretation of a legal material;

3) it is necessary to appeal to the jurisprudence and special researches on questions of interest;

4) it is necessary to reveal the need for a legal mediation of the specific relations;

5 ) it is necessary to find out a practice of the normative regulation of the similar public relations and practice of the individual legal influence in similar situations;

6) it is necessary to pay attention to compliance of the considered relations to the interests of personality, society, state and to the possibility of ensuring its protection with economic, social, political, organizational and others means (Kaufman, 2009).

Thus, in order to reveal a gap in the criminal law the law enforcer has to find out a lack of regulation of any case in the branch legal sources and to prove the need of the legal regulation of the corresponding relation proving its legal character. Let us add that the law enforcer has to know not only the criminal legislation, but also to be oriented in other criminal law sources, to realize their interrelations, to understand the criminal law system, to be aware of correlations and interdependence of its elements, to be able to predict that the casual completion of the found gap will rather harmoniously fit in the aforesaid system.

It allows us to conclude that the lacune rules are necessary in the criminal law system not only for "making ready" the subsystems of the criminal law and institutions of the existing public relations or for the subsystem existence of the criminal law relations or for development of legal consciousness and level improvement of professional competence of the law-enforcer, but also for associations of all these components in order to observe, reveal and protect the rights of each person in the criminal law sphere in the territory of a certain state and even beyond it. The existence of lacune rules in the system saving mechanism of the criminal law and, consequently, in the branch system provides its optimal and uninterrupted functioning that is vital for the timely decision for branch objectives and for the achievement of the corresponding goals.

The system saving mechanism maintains the balance and the balanced condition of the criminal law branch with the help of the socalled "collision" norms and specialized juridical norms intended for solution between juridical norms. The main feature of these norms is their participation in regulation of the public relations with those juridical norms whose contents appeal to the law enforcer and other participants of legal communication (Criminal law..., 2008; Alekseev, 1973). At the same time they are relatively independent from the functional 
mission, because any collision norm regulates actions of a law enforcer through a choice of one of the collision norms in case of a certain situation. It stands for a sufficient autonomy of these norm groups in the legal system and their specific subject of regulation. It also emphasizes their validity and meaning, "the greatest powerful beginning" they possess (Course of..., 2001), due to which they are capable to resolve a conflict between juridical norms, to establish an order in implementation of pushing the standard instructions together and to stabilize the legal system and to support its balance. By the fact of their existence the collision norms release the law-making bodies from the further explanation. But what is the most important is that they significantly facilitate the law-enforcement activity because they give the reference points of how to behave in a certain case and which judicial norms to choose.

Nowadays, an independent subsystem of collision norms is absent both at the branch and at the inter-branch levels. Some collision instructions can be met in various legal acts: for example, in Subparagraphs 2 and 3 Article 2 of the Federal law "On imposition of the Criminal Code of the Russian Federation" dated June 13, 1996 and Article 10 of the Criminal Code of the Russian Federation. Special rules of permission of temporal collisions between judicial norms and instructions were accepted in different times.

The above said helps us to conclude that collision norms are an important system saving factor for the criminal law branch admitted as a necessary element of the mechanism specializing on preservation, protection of integrity of the legal system (and the criminal law system in particular) from any external and internal factors counteracting the normal functioning.

To sum up, let us note that the system saving mechanism in the criminal law is a system of the system saving elements providing integrity and unity of the branch; it is a peculiar structure, an internal device that forces necessary actions connected between each other and at the same time mobile elements of the system criminal law. This mechanism is necessary for each branch, because without it the law becomes powerless, not capable to perform the functional mission (there would be a disunity of the criminal law, their isolation from the real needs of legal practice and legal relationship, the quantity of collisions would increase disconnection in the system of legal sources of the law).

Thus, this is one of the most important means of self-governance and self-regulation in the law (and in the criminal law in particular). The elements of the system saving mechanism carry out particular processing of the criminal law material, determine the content and implementation of each criminal precept of the law and institution, penetrate all the legal sources of this branch of the law, influence emergence and development of the criminal legal relations, i.e. support the intra-branch unity and coherence in the aforesaid legal phenomena, thereby providing systemacity in the criminal law and its branch integrity. The system saving mechanism states, animates and humanizes legal reality with the help of adaptation and innovation of the system elements of the criminal law in relation to realities of the modern public relations due to their completion of limited opportunities and corrections leading to the exact setup of mechanisms of the criminal law regulation and elimination of defects in the branch system. Thus, the intra-system and logical contradictions are eliminated in the contents of the criminal law; the continuity and constancy in the criminal law and perception of progressive provisions in other legal subsystems are provided and also the impractical legal instructions are revealed. 


\section{References}

Alekseev, S.S. Problemy teorii prava [Problems of the theory of law].

Babaev M.M., Pudovochkin Iu.E. (2012). Printsipy ugolovnogo prava i osnovaniya ego ustoichivogo razvitiya [The principles of criminal law and bases of its sustainable development], in Biblioteka kriminalista [Library of the criminalist].

Bezverhov, A.G. Administrativnaya preyuditsiya v ugolovnom prave Rossii [Administrative preyudition in criminal law of Russia], in Aktual'nye problemy ugolovnogo prava, kriminologii, ugolovno-ispolnitel'nogo prava [Actual problems of criminal law, criminology, criminal and executive law].

Kurs rossiiskogo ugolovnogo prava. Obshchaya chast' [Course of Russian criminal law. General part]

Iamasheva, E.V. (2009). K voprosu o vosstanovlenii instituta administrativnoi preyuditsii v ugolovnom zakone Rossii [To a question of restoration of institute of administrative preyudition in criminal law of Russia] in Zhurnal rossiiskogo prava [Magazine of Russian law]

Inogamova-Hegai, L.V. (2014). Kontseptual'nye polozheniya reformirovaniya Ugolovnogo kodeksa RF [Conceptual ideas of reforming of the Criminal Code of the Russian Federation] in Kriminologicheskii zhurnal Baikal'skogo gosudarstvennogo universiteta ekonomiki i prava [Criminology journal of Baikal National University of Economics and Law]

Kaufman, M.A. Probely v ugolovnom prave I sudeiskoe usmotrenie [Gaps in criminal law and judicial discretion]. Moscow, 2009. 344 p. (In Russian)

Komissarova, E.G., Kuznecova, O.A., Borisevich, G.Ja. (2013). Mezhotraslevaya preyuditsiya kak sredstvo protivodeistviya ekonomicheskoi prestupnosti [Cross-sectoral prejudgement as an economical crime countermeasure] in Kriminologicheskii zhurnal Baikal'skogo gosudarstvennogo universiteta ekonomiki i prava [Criminology journal of Baikal National University of Economics and Law]

Lazarev, V.V. Pretsedentnoe reshenie Konstitutsionnogo suda Rossiiskoi Federatsii [Case decision of the Constitutional Court of Russian Federation] (2009) in Zhurnal rossiiskogo prava [Magazine of Russian law]

Lopashenko, N.A.Osnovy ugolovno-pravovogo vozdeistviya [Criminal law' influence bases]. St. Petersburg, 2004. 338 p. (In Russian)

Mal'tsev, V.V. Printsipy ugolovnogo prava [The principles of criminal law]. Volgograd, 2001. 266 p. (In Russian)

Naumov, A.V. Rossiiskoe ugolovnoe pravo [Russian criminal law. Course of lectures in $3 \mathrm{v}$ ]. Moscow, 2011, v.1 General part. 768 p. (In Russian)

Pan'ko, K.K. Fiktsii v ugolovnom prave v sfere zakonotvorchestva I pravoprimenenii [Fiction in criminal law in the lawmaking sphere and law enforcement]. Avtoref. diss. ... k.iu.n. Iaroslavl', 1998. 19 p. (In Russian)

Po delu o proverke konstitutsionnosti polozheniya chasti pervoi stat'i 188 Ugolovnogo kodeksa RF v svyazi s zhaloboi grazhdanki M.A. Aslamazyan [On the case of constitutionality check of p. 1 a.188 of Criminal Code of Russian Federation in connection with complaint of citizen M.A. Aslamazian]: Resolution [passed by the Constitutional Court of Russian Federation on 27 may, 2008], Rossiiskaya gazeta. 2008. 07 june. (In Russian) 
Skoblikov, P.A. (2009).Preyuditsiya aktov arbitrazhnyh sudov v ugolovnom protsesse: novoe prochtenie [Preyudition of the acts of arbitration courts in criminal trial: new reading]. in Zhurnal rossiiskogo prava [Magazine of Russian law]

Tille, A.A. Vremya, prostranstvo, zakon [Time, space, law]. Moscow, 1965, 201 p. (In Russian)

Ugolovnoe pravo. Obshchaya chast' [Criminal law. General part]. Textbook. Kozachenko I.Ia. [et al.]. Moscow, 2008. 720 p. (In Russian)

Vlasenko, N.A. Kollizionnye normy v sovetskom prave [Conflict norms in soviet law]. Irkutsk, 1984. 100 p. (In Russian)

Volkov, K.A. (2013). Deyatel'nost' politsii po protivodeistviyu prestupnosti: kollizionnye problemy pravovogo regulirovaniya neobhodimoi oborony i ugolovno-pravovogo zaderzhaniya [Police crime counteraction activity: conflict of laws on legal regulation of justifiable defense and criminal cuastody]. in Kriminologicheskii zhurnal Baikal'skogo gosudarstvennogo universiteta ekonomiki i prava [Criminology journal of Baikal National University of Economics and Law]

\title{
Системосохраняющий механизм
}

в российском уголовном праве

\author{
А.В. Денисова \\ Самарский университет \\ Россия, 443011, Самара, ул. Академика Павлова, 1
}

В статье проанализированы особенности функичионирования системосохраняющего механизма в уголовном праве; дана подробная характеристика его структуры и содержания, выявлено значение этого механизма для обеспечения отраслевой целостности. Благодаря этому механизму в уголовно-правовой сфере происходит своеобразная обработка отраслевой системь, обеспечивается необходимое сочленение и гармонизация ее элементов. Тщательно исследованы такие его структурные элементы, как принципы, цели и задачи уголовного права, отраслевые презумпции и фикции, преюдиции, пробельные и коллизионные правила. Сделан вывод, что исследуемый механизм является одним из средств саморегулирования в уголовном праве.

Ключевые слова: системность права, уголовное право, системосохраняющий механизм, принизипы, цели и задачи уголовного права, отраслевые презумпџии и фикции, преюдици, пробельные и коллизионные правила.

Научная специальность: 12.00.00 - юридические науки. 